\title{
Legal Protection of Foundations of Land Ownership Which Is Named to the Management
}

\author{
Tania Tasmaya Rarasati; Hariyanto Susilo; Iwan Permadi \\ Master of Notary, Faculty of Law, Brawijaya University, Indonesia \\ http://dx.doi.org/10.18415/ijmmu.v8i3.2491
}

\begin{abstract}
The purpose of conducting this research is to analyze and determine the status of land ownership by foundations whose initial ownership was before the enactment of the Law on Foundations on behalf of the foundation management. The research method used is a sociological juridical research. While the research approach used is a statutory approach, history, cases, and a philosophical approach. The results of the study show a tendency that the existence of a foundation which has historically originated from relying on colonial doctrine, jurisprudence, and regulations, makes the foundation's status as a legal entity does not appear firm. Thus, this has implications for the foundation's rights to manage and own the foundation's wealth and assets. The foundation's wealth and assets are actually important entities for the foundation in carrying out the foundation's activities in order to achieve the foundation's goals. The Law on Foundations only existed in 2002, which once stated that foundations were legal entities engaged in social, religious and humanitarian fields. The positive impact that arises after the promulgation of regulations on foundations is that it makes it easier for foundations to take legal actions, especially in terms of managing the foundation's assets. However, in its development, law must be able to support the sociological development of the legal subject itself. The Law on Foundations is not sufficiently capable of providing legal protection for foundations related to ownership of land rights by foundations. Although under transitional provisions, it has been mandatory for foundations within a certain period of time to adjust the Foundation's Articles of Association and Bylaws with the new law. However, there are no articles that specifically regulate how the transfer of ownership status of foundation assets from before the enactment of the Law on Foundations until after the enactment of the Law on Foundations. So, this research leads to the conclusion that it is necessary to include articles in the Law on Foundations that regulate the ownership status of foundation assets and their transfers.
\end{abstract}

Keywords: Foundation; Foundation Ownership; Foundation Land Rights

\section{A. Introduction}

The needs of the people who want a forum for social activities and aim at the social, religious and humanitarian fields have been realized with the issuance of Law Number 16 of 2001 Jo Law Number 24 of 2008 concerning Amendments to Law Number 16 of 2001 concerning foundations. Since the time of 
the Dutch East Indies government, the form of a foundation was a form that was widely used in society. Prior to the existence of the law on foundations, foundations were customary laws that arose automatically in society and arose out of necessity.

A foundation is a non-profit legal entity established by a legal subject or more, which is engaged in humanitarian, religious and social affairs. In the Big Indonesian Dictionary, a foundation is defined as "a legal entity that has no members, is managed by the Management and established for social purposes." ${ }^{1}$

Rochmat Sumitro defines a legal entity as an entity that can have assets, rights and obligations like an individual. ${ }^{2}$ Meanwhile, the definition of legal subjects according to Abdulkadir Muhammad, in the Indonesian Civil Law book, states that legal subjects are people, namely supporters of rights and obligations. ${ }^{3}$

The notion of a foundation as a legal entity was put forward by Scholten, who stated that a foundation is a legal entity whose elements of its own assets, which come from an act of separation, specific purposes, and equipment. ${ }^{4}$ From the above understanding, it can be concluded that a foundation is a legal entity that has no members, has separate assets, and can carry out legal actions. The foundation was originally used as a translation of the term "Stichting" which comes from the word Stichen which means to build. ${ }^{5}$

Foundations are known as institutions and general legal entities in the legislation prior to the independence of the Republic of Indonesia. Among them are the Civil Code (Burgerlijke Wetboek), Civil Procedure Regulations (Rechtsvordering), and the Indonesian Commercial Law Code (Wetboek van Koophandel voor Indonesie). The word institution is listed in Articles 365, 899, 900, and 1680 of the Civil Code (KUHPerdata), Article 6 paragraph (3) Rechtvordering (Rv), and Article 229a.bis of the Indonesian Commercial Code (KUHD). Several articles in the Civil Code mention a foundation as an institution including Articles 365, 899, 900, and 1680; which contents as follows:

"Pasal 365: Dalam segala hal, bilamana Hakim harus mengangkat seorang wali, maka perwalian itu boleh diperintahkan kepada suatu perhimpunan berbadan hukum yang bertempat kedudukan di Indonesia, kepada suatu yayasan atau lembaga amal yang bertempat kedudukan disini pula yang mana menurut anggaran dasarnya, akta-akta pendiriannya atau reglemennya berusaha memelihara anakanak belum dewasa untuk waktu yang lama (Article 365: In all cases, if a judge must appoint a guardian, the guardianship may be ordered to an association with legal status domiciled in Indonesia, to a foundation or charity which is domiciled here which according to its articles of association, deeds its establishment or regulation seeks to maintain immature children for a long time)".

"Pasal 899: Untuk dapat meniKeputusan Menteri Agama sesuatu berdasarkan surat wasiat, seseorang harus sudah ada pada saat si pewaris meninggal, dengan mengindahkan peraturan yang ditetapkan dalam pasal 2 kitab undang-undang ini.Ketentuan ini tidak berlaku bagi orang-orang yang diberi hak untuk mendapatkeuntungan dari suatu lembaga-lembaga (Article 899: To be able to comply with the Decree of the Minister of Religion based on a will, a person must already be there when the heir dies, with due observance of the regulations stipulated in article 2 of this law. This provision does not apply to people who are granted the right to benefit. of an institution)".

\footnotetext{
1 DepartemePendidikan Nasional Republik Indonesia, Kamus Besar Bahasa Indonesia Dalam Jaringan, http://pusatbahasa.diknas.go.id/kbbi/index.php.

${ }^{2}$ C.S.T. Kansil, Jm Christine Kansil, Pokok-pokok Badan Hukum, (Jakarta: Sinar Harapan, 2002), hlm 2.

${ }^{3}$ Abdulkadir Muhammad, Hukum Perdata Indonesia, Cet 1 (Bandung:PT. citra Aditya Baksi,2000), hlm.26.

${ }^{4}$ Gatot Suparmono, Hukum Yayasan di Indonesia. Cet I, (Jakarta:Rieneka Cipta,2008), hlm. 3.

${ }^{5}$ Arie Kusumastuti Maria Suhardiadi, Hukum Yayasan Di Indonesia (Berdasarkan Undang-Undang Republik Indonesia Nomor 16 Tahun 2001 tentang Yayasan), Cet 1, (Jakarta: PT ABADI, 2002), hlm.3.
} 
"Pasal 900: Setiap pemberian hibah dengan surat wasiat untuk kepentingan lembaga kemasyarakatan, badan keagamaan, gereja atau rumah fakir-miskin tidak mempunyai akibat sebelum pemerintah atau penguasa yang ditunjuk oleh pemerintah memberi kuasa kepada para pengelola lembaga-lembaga itu untuk menerimanya (Article 900: Every grant given by a will for the benefit of social institutions, religious bodies, churches or houses of the poor has no effect before the government or the authorities appointed by the government authorize the managers of these institutions to receive it)".

"Pasal 1680: Hibah-hibah kepada lembaga umum atau lembaga keagamaan tidak berakibat hukum, kecuali jika Presiden atau pembesar yang ditunjuknya telah memberikan kuasa kepada para pengurus lembaga-lembaga tersebut untuk menerimanya (Article 1680: Grants to public institutions or religious institutions have no legal effect, unless the President or a superior appointed by him has authorized the management of these institutions to receive them)".

The establishment of foundations in Indonesia currently refers to Law Number 16 of 2001 in conjunction with Law Number 28 of 2004 concerning Amendments to Law Number 16 of 2001 concerning Foundations. The status of a foundation as a legal entity is stated in Article 1 of Law No. 16 of 2001. The establishment of a foundation will receive legal certainty valid for 1 year after the foundation law is issued; but that does not mean that before the foundation law, there was a legal vacuum regarding foundations. The reason for the enactment of the foundation law was because of the misuse of the foundation as a forum to enrich the organ of the foundation itself.

The absence of a law regulating foundations at that time caused uncertainty about the definition of a foundation. The absence of strict limits on the activities of the foundation and clear aims and objectives for the establishment of the foundation resulted in many deviations from the foundation's goals, namely as a non-profit organization engaged in the social, religious and humanitarian fields. On August 6, 2001 a law was issued regulating foundations, namely Law number 16 of 2001 concerning foundations.

Before the Law on foundations was enacted; objectives in the social, religious and humanitarian fields are not strictly regulated. This then often leads to a deviation from the foundation's profit base from a social goal to an institution that pursues profit. With the existence of the foundation law, it changes the paradigm for the existence of foundations that were established before and after the enactment of the law on foundations. So that the enforcement of this foundation law is preventive and repressive. The preventive nature lies in preventing the use of the foundation to seek profit through the establishment of the foundation and this repressive nature lies in the sanctions against the old foundation whose statutes are not adjusted to the foundation law that has been enacted.

Right now, land ownership is very important for the State, Nation and the Indonesian people. Legal certainty to own land rights is a priority, especially in the land sector. However, in practice, this land issue always creates conflicts or disputes. This can be seen from the number of claims over land, starting with complaints from a party containing claims or objections to ownership of land rights, both ownership and status of the land. One of the land disputes that occurred was a land dispute belonging to the foundation " $\mathrm{X}$ " which is domiciled in Malang City. In this case, foundation "X" wants to take back its land; prior to the enactment of the foundation law, the land was in the name of the management of the foundation " $\mathrm{X}$ ". The cause of this conflict was because the manager whose name was stated on the certificate had passed away, and did not give a will that the land belonged to the foundation, while the heirs felt that the land was the private property of his parents, not the foundation " $\mathrm{X}$ ". This has become a prolonged conflict for the " $\mathrm{X}$ " Foundation in Malang, where until now the " $\mathrm{X}$ " Foundation is led by two different factions. 
In this case, the author wants to discuss land ownership by foundations on behalf of the management before the enactment of Law Number 16 of 2001 in conjunction with Law Number 28 of 2004 concerning Amendments to Law Number 16 of 2001 concerning foundations. The author is interested in writing about this issue because there are many conflicts or problems that arise about seizing land assets belonging to the foundation on behalf of the management before the birth of the Law on foundations. Departing from the above background, the author formulates the first problem, what is the legal status of ownership of land rights of foundations after the enactment of the foundation law. Second, what is the form of legal protection for foundations over ownership of land rights on behalf of the management before the foundation law comes into effect.The research method used is juridical normative with a legal, historical, case, and philosophical research approach.

\section{B. Methodology}

This research is utilizing a sociological juridical research method. While the research approach used is a statutory approach, history, cases, and a philosophical approach. Hence, this research tries to foster a more complete understanding of the conceptual bases of legal principles and of the combined effects of a range of rules and procedures that touch on a particular area of activity.

\section{C. $\quad$ Findings and Discussion}

Land ownership rights are one of the types of land rights regulated by Law Number 5 of 1960 concerning Basic Agrarian Regulations (UUPA). Land rights in this law, apart from being able to be linked to certain land parcels and certain subjects; can also be seen as an institution, which is a species (special form) of land rights. ${ }^{6}$

From the point of view of the land, the title to land is a legal status or position with certain characteristics and characteristics that distinguish the land from other land rights. Whereas when viewed from the point of view of the subject, ownership rights to land are a legal relationship between the subject and a certain land parcel, which gives certain powers and obligations of that subject, both general and specific in nature, in relation to the land. However, if we look at it as an institution, the property rights contain the powers and obligations that a subject can have, when the subject owns the land with the status of property rights. ${ }^{7}$

As for the nature of ownership rights over land in question, we can see in Article 20 paragraph 1 which states that property rights are rights that are: hereditary, strongest, and the fullest that a person can have over land. This is done by keeping in mind the provisions of Article 6, namely that all land rights have a social function. The nature of the land, which is hereditary, strongest, and fulfilled, must always be attached to the right of ownership over the land, because rights that do not have these three characteristics at once are not property rights. ${ }^{8}$ The granting of the strongest and fullest nature is intended to show the difference with other rights, that property rights are the strongest and fullest rights among land rights, while hereditary nature means that property rights can be inherited to the heirs of the right holder. So that ownership can be continued by his heirs. That is why the period of time for land ownership is not determined, unlike land use rights or building use rights which have a period of time.

\footnotetext{
${ }^{6}$ Boedi Harsono, UUPA Sedjarah Penjusunan Isi dan Pelaksanaannja Bag.Pertama, Jil.II, (Jakarta:Djambatan, 1971), hlm.52.

${ }^{7}$ Ibid.

${ }^{8}$ Effendi Perangin, Hukum Agraria Di Indonesia: Suatu Telaah Dari Sudut Pandang Praktis Hukum, (Jakarta:Rajawali, 1986), hlm. 236.
} 
In relation to the subject who can have land rights, namely property rights, it turns out that not all people or legal entities can own land with ownership rights. This is because only Indonesian citizens can make ownership rights according to article 21 paragraph 1 . As for legal entities, it is determined that only legal entities stipulated by the government can have ownership rights over land with conditions as stipulated in Article 21. paragraph 2 and article 49.

This means that people who have another nationality or foreigners cannot have ownership rights over land even for those who have dual citizenship, then their status is still equal to foreigners. The act of transferring title to land to foreigners or to those with dual nationality is prohibited and null and void, while the land falls to the state in accordance with Article 26 paragraph 2.

The rights of other parties who burden it continue and all payments that have been received by the owner cannot be reclaimed, even if for foreigners or dual citizens. If they obtain property rights because of inheritance without a will or because of a mixture of assets due to marriage, according to the provisions of Article 21 paragraph 3, they are required or obliged to report said rights within 1 year of obtaining it. If this right is a property, if it is not transferred to another party who meets the requirements according to the 1-year time limit, then the title to the land is canceled because the law and the land fall to the state. This is valid provided that the rights of the other party who burden it are still recognized and last until the termination period of that provision. The same thing also applies to Indonesian citizens who have property rights and then lose their citizenship with a stipulated period of time to relinquish this right, calculated from the time they lose their citizenship.

During its development, it turns out that humans are not the only legal subjects. To support their actions, and also in exercising their rights and obligations, the law divides its subjects into two, namely humans (naturlijk rechtpersoon) and legal entities (rechtpersoon). Legal entities also have the same position as legal subjects, and can carry out legal relations or legal actions. That is why, then emerges a reality that it is not only humans who are the subject of law; this is because it is not only humans who undergo their own relationship, sometimes humans have relationships with other parties. This principle then underlies the existence of legal entities as the second legal subject after humans.

Humans who have common interests, fight for a certain goal, come together, and unite themselves. They create an organization; they choose a board that will represent them. They enter and accumulate wealth, they set rules for their behavior in relation to other people. ${ }^{9}$

For legal entities, ownership of land rights in the form of ownership rights has been regulated in Government Regulation Number 38 of 1963 concerning the Appointment of Legal Entities That Can Have Ownership Rights to Land. Article 1 states that one of the legal entities granted ownership rights to land rights is a legal entity that operates in the social and religious fields, so foundations are included in it. This provision also answers the formulation of the first problem, namely that foundations have power over ownership of land rights in the form of property rights, which is then reaffirmed through the Law on Foundations by stating that foundations are legal entities engaged in religious, social, and humanitarian fields.

Law functions as protection for the benefit of humans or in other words so that humans are protected, the law must be implemented. Law enforcement can take place normally, peacefully, but it can also occur because of lawlessness. Law violation occurs when a certain subject does not fulfill the obligations that should be carried out, or because it violates the rights of another legal subject. Legal subjects whose rights are violated must receive legal protection. ${ }^{10}$

${ }_{9}^{9}$ Ali Rido, Badan Hukum dan Keudukan Badan Hukum Perseroan, Perkumpulan, Koperasi, Yayasan, Wakaf, (Bandung:Alumni, 1977), hlm.3.

${ }^{10}$ Mukhti Fadjar, Tipe Negara Hukum, (Malang: Bayumedia, 2004), hlm.28-29. 
From the description above, the role of law is very important to provide protection. Thus, the purpose of legal protection is the protection of legal subjects and other legal subjects so that the interests of each person can be protected and that protection can be carried out by means of preventive and repressive means. This is very relevant as a matter that must be applied to foundations in the context of ownership of land rights as an asset of the foundation in carrying out its activities in order to realize the foundation's goals.

The Foundation Law currently only regulates how foundations can obtain sources of wealth. It does not at all explicitly regulate how the wealth is managed, transferred and used for the purposes of the foundation. Article 26 paragraph (4) of the Foundation Law only states that all the assets of a foundation must be used to achieve the goals of the foundation. This norm is very counterproductive to the reality that shows that foundations still often experience legal problems in the realm of land rights ownership. Whereas the existence of land rights for a foundation is essential, because it is directly related to how the foundation can run and carry out its activities, of course all of these are also a series of instruments to achieve the foundation's goals.

The most concrete form of legal protection for foundations in order to have a clear legal status, related to how foundations can acquire, manage and control foundation assets in the form of land rights is to enforce the norms in the Foundation Law as legal reform. This will provide more certainty for the foundation. In addition, it is very necessary to regulate what if the foundation experiences a dispute in the field of land rights, as an effort for the foundation to maintain the legal status of the land rights under its control. Both are forms of preventive and repressive legal protection, as well as legal protection which is expected to be able to maintain the dignity of the foundation as a legal entity engaged in the religious, social and humanitarian fields.

\section{Conclusion}

During its development, it turns out that humans are not the only legal subjects. To support their actions, and also in exercising their rights and obligations, the law divides its subjects into two, namely humans (naturlijk rechtpersoon) and legal entities (rechtpersoon). Legal entities also have the same position as legal subjects, and can carry out legal relations or legal actions. Why then emerges a reality that not only humans are legal subjects, this is because not only humans undergo their own relationships, sometimes humans establish relationships with other parties, this principle then underlies the existence of legal entities as second legal subjects after humans.

Ownership of land rights is an essential requirement for legal subjects. The control over these rights is the basis for legal subjects to be able to live on the land. Legal entities, including one of the entities or legal subjects who obtain the right to control it. This is because legal entities also carry out their activities and can be legally responsible for them. Property rights are rights that are fulfilled and are realized with the freedom for the ruler to take advantage of their property while still guided by the statutory regulations on agrarian matters.

Land disputes that may be experienced by many foundations in Indonesia, of course, become the background for the urgency of establishing legal regulations that can support legal protection for foundations over control of land rights. Government Regulation Number 38 of 1963 is the only basis for legal entities to have ownership rights over land. However, of course these regulations require a higher norm hierarchy and status so that they can provide full legal protection.

The legal regulations in question are manifested in the inclusion of articles in the Foundation Law regarding how foundations can obtain rights to land, particularly property rights, as well as how the 
exploitation mechanism for foundations to defend their rights. Thus, the process of obtaining land rights and resolving disputes that may occur in the future will not burden the foundation.

\section{References}

Books:

Abdulkadir Muhammad, Hukum Perdata Indonesia, Cet 1 (Bandung:PT. citra Aditya Baksi,2000).

Ali Rido, Badan Hukum dan Keudukan Badan Hukum Perseroan, Perkumpulan, Koperasi, Yayasan, Wakaf, (Bandung:Alumni, 1977).

Arie Kusumastuti Maria Suhardiadi, Hukum Yayasan Di Indonesia (Berdasarkan Undang-Undang Republik Indonesia Nomor 16 Tahun 2001 tentang Yayasan), Cet 1, (Jakarta: PT ABADI, 2002).

Boedi Harsono, UUPA Sedjarah Penjusunan Isi dan Pelaksanaannja Bag.Pertama, Jil.II, (Jakarta:Djambatan, 1971).

C.S.T. Kansil, Jm Christine Kansil, Pokok-pokok Badan Hukum, (Jakarta: Sinar Harapan, 2002).

Effendi Perangin, Hukum Agraria Di Indonesia: Suatu Telaah Dari Sudut Pandang Praktis Hukum, (Jakarta:Rajawali, 1986).

Gatot Suparmono, Hukum Yayasan di Indonesia. Cet I, (Jakarta:Rieneka Cipta,2008).

Mukhti Fadjar, Tipe Negara Hukum, (Malang: Bayumedia, 2004).

Article from Internet:

Departemen Pendidikan Nasional Republik Indonesia, Kamus Besar Bahasa Indonesia

Dalam Jaringan, http://pusatbahasa.diknas.go.id/kbbi/index.php.

\section{Copyrights}

Copyright for this article is retained by the author(s), with first publication rights granted to the journal.

This is an open-access article distributed under the terms and conditions of the Creative Commons Attribution license (http://creativecommons.org/licenses/by/4.0/). 